DOI: https://doi.org//10.32839/2304-5809/2020-83.1-1

UDC 81'255.2:316.77:[334.025:005.511

Ageicheva Anna, Vypovska Anastasia

National University "Yuri Kondratyuk Poltava Polytechnic»

\title{
ICT USAGE PECULIARITIES IN STARTUP PROJECTS TRANSLATION
}

\begin{abstract}
Summary. The peculiarities of the use of information and communication technologies in translating the project stage are investigated. Today, there are many competitions for startups that help the project win a cash prize to realize the idea and find investors. It has been proved that a translator in a startup project is a person as an important and necessary team tool to build relationships with potential clients around the world. The success of submitting a project to the international arena depends on many details: translation of the application, presentation, website, necessary audio and video materials, agreements and other legal and economic documentation. Much attention is paid to the study of the use of information and computer technologies in the translation process. The role of translator in startup projection is defined. The main difficulties and peculiarities of translation of various documentation in the startup project are investigated. An analysis of the use of modern ICT in translator work and translation of startup projects is performed. The results of the analytical work in translating the final projects of the Startup School of the National University Yuri Kondratyuk Poltava Polytechnic have been practically applied.
\end{abstract}

Keywords: startup projects, ICT, translation, startup school.

Агейчева А.О., Виповська А.С.

Національний університет «Полтавська політехніка імені Юрія Кондратюка»

\section{ОСОБЛИВОСТІ ЗАСТОСУВАННЯ ІКТ В ПЕРЕКЛАДІ СТАРТАП-ПРОСКТІВ}

Анотація. Досліджено особливості використання інформаційно-комунікаційних технологій в перекладі стартап проєктів. На сьогоднішній день існуе багато конкурсів для стартапів, які допомагають проєкту отримати грошовий приз для реалізації ідеї та знайти інвесторів. Доведено, що перекладач в стартаппроєкті - це людина як важливий та необхідний інструмент команди для налагодження відносин 3 потенційними клієнтами по всьому світу. Успіх представлення проєкту міжнародній арені залежить від багатьох деталей: переклад заявки, презентації, веб-сайту, необхідних аудіо- та відеоматеріалів, угод та інших видів юридичної та економічної документації. Приділено велику увагу дослідженню використання інформаційних та комп'ютерних технологій у процесі перекладу. Визначено роль перекладача в стартап-проєкті. Досліджено основні труднощі та особливості перекладу різної документащії в стартап-проєкті. Зроблено аналіз використання сучасних ІКТ у роботі перекладача та в перекладі стартап-проєктів. Практично застосовано результати аналітичної роботи при перекладі фінальних проєктів Стартап школи Національного університету «Полтавська політехніка імені Юрія Кондратюка». У статті проаналізовані можливості, що пов’язані з перекладацькою діяльністю в освіті, такі як їі здатність викликати стимул навчатися і прищепити мотивацію, упевненість і почуття релевантності студентам. Дослідження певною мірою свідчить про позитивний вплив, оновлення та інновації для майбутніх фрахівців. Під час семінарів стартап школи було переможено багато викликів, таких як відсутність часу та труднощі під час перекладу як для тренерів, так і для дослідників. Розв'язуючи деякі з таких проблем, у цій статті була висунута ідея перекладу в стартап-освіті. Обгрунтовані теоретичні засади, відповідні дослідження та практичні наслідки ціеї ідеї, а також протиставлення стартап-освіти, що визначається цим шляхом до інших педагогічних підходів, дебатів і рамок. Охарактеризовано різні інструменти, методи й підходи з різних галузей, які містять практичні поради викладачам і студентам у їхніх спробах досягти успіху.

Ключові слова: стартап проєкти, IKT, переклад, стартап школа.

Droblem statement. Nowadays, there are - a lot of competitions for startups that help the project get a cash prize for implementation, find investors, and get into a world business environment. A translator in the startup team is an essential tool and an important part of the team for building relationships with potential clients around the world. Most of the success depends on translation of the application, presentation, agreements and other types of legal and economic documentation, but the translation process has a number of peculiarities and difficulties. The main focus of this paper is on the analysis of various ICT tools for a quality translator work in a startup project.

The latest research and published works analysis. Startup project is a unique opportunity to express the idea to the world. ICT can help a translator in a startup team work efficiently and quickly. Today scientists and linguists pay a lot of attention to the usage of information and computer technology in the translation process. Machine translation algorithms were described by linguists John Catford [2], Martin Kay [7], John Hutchins [5], as well as the world's largest corporations like Google, Skype and Microsoft. The American Translators Association constantly explores the usage of ICT in translations. Imperial College London has conducted a survey in which more than 800 professional translators from 54 countries participated. The result of this survey: $82.5 \%$ of translators use automated translation programs in their professional activities [6]. It was noted that the most popular among translators are software solutions such as SDL Trados, Wordfast, Déjà Vu, STAR Transit, OmegaT.

Identification of previously unsettled parts of the general problem. It is difficult to imagine the successful development of a particular type of activity without interconnection with other 
"Молодий вчений" • № 7.1 (83.1) • липень, 2020 р.

areas of human knowledge. Accordingly, one of the most important elements for the success and effectiveness of specialists in a particular professional sphere is the integrative nature of the interaction or a competent, effective organization. The tasks of linguists will be solved more successfully with the help of modern information and computer technologies. ICT are able to simplify the translation process of different complexity. Computer technology fits into the current trends of globalization, the expansion of economic and political relations and intercultural interaction.

The main purposes of this paper are:

- to define the role of a translator in a startup project;

- to investigate what main difficulties and peculiarities of the startup documentation translation;

- to do an analysis of modern ICT use in the translator work;

- to determine the ICT usage in startup projects translation.

The results of this analytical work will be practically applied in the the final projects translation of Poltava Polytechnic Startup School.

The main part. Creating a startup project is a complex and responsible process. At the same time, the startup team should not only provide general information about the project, but also talk about the financial part, business model, market prospects and the maintenance team. Filling out an application in English is only a small part of the iceberg. It is important not only to talk about the project, the main goal is to interest the right people, and this is often a difficult task, even in their native language. Even if the startup leader is confident in his knowledge of English, it is better to entrust the professionals with at least editing. It's not enough to have an idea that will work perfectly. It is important to be able to convey it in a form that may interest potential investors and mentors.

A startup is successful if it solves certain problems and can run not only within one country, but throughout the world. In order to inform about the project, the team needs to translate presentations, promotional materials and a website into English. It is also important to entrust the task to professionals, since poor-quality translation is not only a waste of money and damage to the image of the project, but also a loss of time, which has a striking value among startups teams.

One day startup teams that are developing innovative products face the fact that technology must be patented for protection. The purpose of patenting is to secure exclusive rights to manufacture and sell products containing inventions in a certain geographical territory. Translator in a startup team needs to translate patent documentation. This is one of the most important tasks, which has a number of features and difficulties in the translation process.

When translating such documentation, accuracy in the description of the invention is "a must". Any misrepresentation of information here can lead to serious consequences. Errors and inaccuracies in the translation may cause complications during the examination of a patent application, a loss in a patent dispute and a reputation reduction.

In modern sources of information, patents are "security documents certifying and protecting the rights of authorship of an invention". The objects of patent rights include the results of intellectual activity in the scientific, technical and design fields. Moreover, patents exist in the following types: patent for an invention, patent for utility model, patent for an industrial design [1].

Traditionally, the following parts of a patent are distinguished:

1) bibliographic description of the invention;

2) introductory paragraph (technical field to which the invention relates);

3) the purpose of the invention, a brief statement of the essence of the invention;

4) a detailed (full) description of the invention, a description of the design drawings, examples of invention embodiments;

5) patent claims.

Depending on the country of patenting, the composition of the objects of patenting may vary.

During the translation process, the translator has to deal with peculiarities of "patent language": the widespread usage of clichés in patent documentation, the presence of a large number of synonyms, tautologisms and archaisms [3]. What is more, the problem of polysemantic words translation often appears. Linguists should always be guided by the context, since the same word can have different meanings depending on where and when it is used. For example, the concept of often used English word "a customer", depending on the context, can have a number of meanings in Ukrainian: "клієнт", "заловник", "споживач", "користувач".

Another example of a word that has different meanings is the verb "to meet": "to meet current goal" - "відповідати поточним иілям", "tо meet a problem"- "вирішувати проблелу", "to meet obligations" - "виконувати зобов'язання", "able to meet competition"- "конкурентоспроложний".

Another type of translation that the translator works with in a startup project is the translation of marketing information. It should be noted that existing texts translations of this sphere are sometimes ineffective, and in some cases can lead to the failure of the entire campaign to promote the product due to ignoring the specifics of marketing texts. Consequently, with an unprofessional translation the main communicative-pragmatic function of the marketing text is lost - the conviction of a potential buyer that he needs the company's product. Accordingly, it is necessary to find out what are the lexical and grammatical features, that allow to perform the main communicative function, and also how to save these characteristics during translation.

Using marketing texts, the following tasks are performed:

1) a brand image creation;

2) an increase in sales due to information transfer about the company's product/ service to the target audience;

3) a satisfaction increase with the product/ service and strengthening customers loyalty to the brand;

4) a presentation of the competitive advantages of the product/ service [4].

Another distinctive feature of marketing texts, which causes enormous difficulties for translation, is the fact that marketing texts are non-literal in nature. That is why when translating texts of this subject, it is necessary, first of all, to focus not on 
the accuracy of the translation and the complete transfer of the author's style, but on the effective transmission of the message to the reader / buyer by means of the target language. The basic quality indicator is the comprehensibility and accessibility of information for the target audience and, accordingly, the creation of a positive reaction to it.

To optimize the translation process, translators need to actively use modern information technologies. The usage of the newest methods allows to achieve high-quality and efficient translation of large volumes of information.

Translators use Internet resources both for professional communication and searching for necessary linguistic information. Nowadays electronic dictionaries (ABBYY Lingvo, Multitran, Multilex) and special software often help translators automate and optimize the translation process.

Automated translation (Computer Assisted Translation, CAT) is the software used by the human translator in the translation process to increase productivity. The Machine Translation (MT) is such a computer technology when translating from one language to another is done by computer program without human intervention.

Automated translation programs allow to use previously translated texts. During the translation process, the program saves in the translation memory (in the database) the original and translated segments of the text, which are called translation units. Every time the translator starts translating a new segment of text, this segment is compared with the translation units contained in the database. If the translation memory contains the same or similar text fragment, the program, having analyzed the database, finds it and automatically substitutes it in the translation text instead of the original fragment. If the option proposed by the program is an inaccurate coincidence, then the translator can edit it, and add it to the translation memory, due to which the information capacity of the translation memory is constantly increasing.

The start-up project translator will work much faster and more efficiently, because the translation of the main project information and the basic terminological units will already be saved in the database, and it only will be a need to adjust and create the required style, depending on the type of document.

A translation automation system is, first of all, a tool that facilitates the work of a translator. Currently, companies such as SYSTRAN SOFTWARE Inc, Logos Corp., TRADOS Inc., Alis Technologies Inc., CompuServe, the Russian company PROMT and others are developing machine translation systems. Examples of translation programs are the Google Translate Toolkit, Snowball, SDL Language Weaver, PROMT, MemoQ.
We have already found out that the texts with which the translator works in the startup team have a number of features and difficulties in the translation. Mistakes in startup projects are unacceptable. In this regard, the requirements of professional translators for the quality of machine translation are much higher than those of non-professionals.

While working in a startup project, the translator uses ICT not only to simplify the translation process, but also for its required information presentation form. In addition to widely used software products, such as Microsoft Office Pro (Power Point, Microsoft Word, Microsoft Excel are the basic programs), translators often have to use the following software: Adobe Acrobat - a program for working with PDF documents, Adobe Photoshop a program for processing graphics, Adobe Illustrator, Corel Draw - vector graphic editors, Adobe InDesign, Framemaker - layout software, Dreamweaver - a software for web-design. Depending on the project and the task of the translator, it may be necessary to translate audio and video content, as well as their voice acting, dubbing. There are a lot of software for this: AVS Audio Editor, Movavi Video Editor, VirtualDub, Adobe Audition.

As you can see, modern advances in the field of high information technologies, the spread of personal computers and the development of the Internet allow translators to significantly speed up the translation process, make translator work more efficient and effective, increase the productivity and quality of the translation.

Conclusions and ideas for further investigation. Today a translator plays a special role in the startup team and has to not only correctly transfer the source text from a linguistic point of view, but also convey a message and adapt it to the cultural, situational and social characteristics of the target audience. Working in a startup team, the translator deals with special patent, legal and economic documentation depending on the industry and the main goal of the project. Modern information and computer technologies help the translator work faster and more efficiently. ICT include programs of automated and machine translation, as well as the software used for the editing, required information designing and presentation. The main here is to understand all the software usage peculiarities, choose the most appropriate programs or online tools and develop personal work methodology and strategy with the project. Otherwise, the result will be unsatisfactory and may damage the image of the entire startup project. The results of our work are very important and necessary for further research on the peculiarities of ICT usage in the startup projects translation, in particular, the final projects of Poltava Polytechnic Startup School.

\section{References:}

1. Gredina I. V. (2010). Perevod v nauchno-tekhnicheskoy deyatel'nosti [Translation in scientific and technical activities]: uchebnoe posobie. Tomsk : Izd-vo Tomskogo politekhnicheskogo universiteta.

2. Dzh. K. Katford (2009). Lingvisticheskaya teoriya perevoda: Ob odnom aspekte prikladnoy lingvistiki [Linguistic Translation Theory: On one aspect of applied linguistics]. Per. s angl. Izd. 2-e. Moskva: Knizhnyy dom LIBROKOM, 208 s.

3. Komissarov V. N. (1990). Teoriya perevoda (lingvisticheskie aspekty) [Theory of translation (linguistic aspects)]: Ucheb. dlya institutov i fakul'tetov inostrannykh yazykov. Moskva: Vyssh. shk. $253 \mathrm{~s}$.

4. Sheyko A. M. (2016). Perevod marketingovykh tekstov: slozhnosti i osobennosti [Translation of marketing texts: complexities and features]. Homo Loquens. Voprosy lingvistiki i translyatologii. Vyp. 9. S. 147-157.

5. Hutchins J. y H. Somers (1992). An Introduction to Machine Translation. London: Academic Press. 
6. Lagoudaki E. (2008). The Value of Machine Translation for the Pro-fessional Translator. AMTA-2008. MT at work: Proceedings of the Eighth Conference of the Association for Machine Translation in the Americas, Waikiki, Hawaii, October 21-25, p. 262-269.

7. Martin Kay (1980). The Proper Place of Men and Machines in Language Translation. CSL-80-11 Research Report, Xerox Palo Alto Research Center, Palo Alto, CA. Reprinted in 1997 in Machine Translation 12: 3-23, 1997.

8. Zetzsche J. (2007). Machine Translation Revisited. Translation Journal. Volume 11, No. 1 , January. URL: http://www.translationjournal.net

\section{Список літератури:}

1. Гредина И. В. Перевод в научно-технической деятельности: учебное пособие. Томск : Изд-во Томского политехнического университета, 2010.

2. Катфорд Дж. К. Лингвистическая теория перевода: Об одном аспекте прикладной лингвистики. Пер. с англ. Изд. 2-е. Москва : Книжный дом ЛИБРОКОМ, 2009. 208 с.

3. Комиссаров В. Н. Теория перевода (лингвистические аспекты) : Учеб. для институтов и фракультетов иностранных языков. Москва : Высш. шк., 1990. 253 с.

4. Шейко А. М. Перевод маркетинговых текстов: сложности и особенности. Ноmo Loquens. Bonpocb лингвистики и транслятологии. 2016. Вып. 9. С. 147-157.

5. Hutchins J. y H. Somers: An Introduction to Machine Translation. London : Academic Press, 1992.

6. Lagoudaki E. The Value of Machine Translation for the Pro-fessional Translator. AMTA-2008. MT at work: Proceedings of the Eighth Conference of the Association for Machine Translation in the Americas, Waikiki, Hawaii, 21-25 October, p. 262-269.

7. Martin Kay. The Proper Place of Men and Machines in Language Translation. Research report CSL-80-11, Xerox Palo Alto Research Center, Palo Alto, CA, 1980. Передруковано у 1997 рощі в Machine Translation 12: 3-23, 1997.

8. Zetzsche J. Machine Translation Revisited. Translation Journal. Volume 11, No. 1, January, 2007. URL: http://www.translationjournal.net 